\title{
ANALYSIS OF THE FLOW RATE AND THE VOLUMETRIC EFFICIENCY OF THE TROCHOIDAL PUMP BY APPLICATION OF TAGUCHI METHOD
}

\author{
Lozica Ivanović, Blaža Stojanović, Jasmina Blagojević, Gordana Bogdanović, Aleksandar Marinković
}

Original scientific paper

Taguchi method has been used to analyse the influence of the coefficient of the trochoid radius, the number of revolutions and the working pressure on the change in the flow rate and the volumetric efficiency of the trochoidal rotary pump with internal gearing. The coefficient of the trochoid radius, as a geometrical parameter and the number of revolutions and the pressure, as working parameters are considered influential factors in this paper. Taguchi robust design and orthogonal matrices have been applied to design the experiment and to determine the degree of the factors influence, as well as their optimum values. The highest values both for the flow rate and the volumetric efficiency have been obtained for the coefficient of the trochoid radius of 1.375 , the number of revolutions of $2000 \mathrm{~min}^{-1}$ and for the working pressure of 1 bar. The conformation of the experiment shows that Taguchi method can be successfully used for selection of the optimal combination of parameters so that the maximum volumetric efficiency of the trochoid pump can be achieved.

Keywords: ANOVA; flow rate; gerotor; Taguchi method; trochoidal pump; volume efficiency

Analiza protoka i volumenskog stupnja iskoristivosti trohoidne pumpe primjenom Taguči metode

Izvorni znanstveni članak

Primjenom Taguči metode u radu je analiziran utjecaja koeficijenta polumjera trohoide, broja okretaja i radnog tlaka na promjenu protoka i volumenskog stupnja iskoristivosti trohoidne rotacijske pumpe s unutarnjim ozubljenjem. Koeficijent polumjera trohoide je geometrijski parametar, a broj okretaja i tlak su radni parametri koji predstavljaju utjecajne faktore u ovom radu. Primjenom metode Tagučijevog robusnog dizajna i ortogonalnih matrica formiran je eksperimentalni dizajn i određen je stupanj utjecaja faktora, kao i njihove optimalne vrijednosti. Za analizirane uvjete eksperimenta, najveće vrijednosti protoka i volimenskog stupnja iskoristivosti dobivene su za koeficijent polumjera trohoide 1.375, broj okretaja od $2000 \mathrm{~min}^{-1} \mathrm{i}$ radni tlak od 1 bar. Potvrda eksperimenta pokazuje svrhovitost primjene Taguči metode za izbor optimalne kombinacije parametara u odnosu na maksimalni volumenski stupanj iskoristivosti trohoidne pumpe.

Ključne riječi: ANOVA; gerotor; protok; Taguči metoda; trohoidna pumpa; volumenski stupanj iskoristivosti

\section{Introduction}

Trochoidal (gerotor) pumps belong to the group of planetary rotary gear pumps with a trochoidal gearing profile. In practice, trochoidal gearing profiles are used both for internal and external gearing. Rotary pumps mainly have internal gearing $[1,2]$.

The gerotor mechanism studied in this paper consists of two movable elements: an internal drive gear with external gearing and an external drive gear with internal gearing. The external gear has one more tooth than the internal one, and the space between their profiles comprises the pump chambers. During the operation, each chamber periodically enters the suction and the discharge zone, while the gear with external gearing has a role of the discharging element $[1 \div 3]$. The fluid flow in gerotor pumps is uniform, and the operation is quiet due to relatively low speed of their working elements. Because of their numerous advantages, gerotor pumps have found wide application.

Functional characteristics of the pump are significantly influenced by the gear pair parameters. The influence of geometric parameters of the gear pair profile and working parameters of the pump on its functional characteristics has been studied in this paper. Taguchi method has been used for the analysis of the change in the flow rate and the volumetric efficiency of the gerotor pump.

Taguchi method is used to reduce the number of experimental tests and thus experimental costs while identifying the most influential factors and determining optimal values of the studied factors [4]. These advantages of Taguchi method have been employed to determine the optimal values of the factors that influence the change in the flow rate and the volumetric efficiency of gerotor pumps.

Kim et al. [5] developed a new methodology for the flow rate control in trochoidal hydraulic pumps that is based on cavitation simulation. This methodology was developed using software packets AMESim \& CATIA V5. A mathematical model of the gerotor pump that can simulate both the gerotor pump and the cycloidal reducer was proposed by Hwang and Hsie [6, 7], while Mohammad Reza designed the elliptical shaped intertooth space of the gear with internal gearing of the gerotor pump in order to minimize wear [8]. Jung Sung-Yuen et al. applied Taguchi method to determine the optimal shape of the rotor and to design pump parameters [9].

In this paper, the possibilities offered by Taguchi method have been utilised to determine the optimal values of the trochoid radius, the number of revolutions and the pressure that will yield as high values of the flow rate and volumetric efficiency as possible. It has been shown that applying this method the time needed to perform experiments and obtain optimal values of the analysed parameters is considerably saved, which is a significant contribution of the paper to this field of study.

Minitab 16 software programme package [10] has been used for statistical processing of experimental results of the flow rate and volumetric efficiency.

\section{Taguchi method}

Taguchi methods are statistical methods developed by Dr. Genichi Taguchi to improve the quality of products [11]. 
Different conditions i.e. changes can cause various deviations in the system thus decreasing its optimal operation. In order to avoid accumulation of such changes, it is necessary to develop robust products that function in an optimal way even in different, variable conditions [12].

Finding design parameters to increase robustness is the core of Taguchi method. A robust design is not directly aimed at solution of the problem; it is aimed at creating a system that functions in all conditions as closely to ideal as possible.

According to Taguchi, the selection of parameters is achieved by experiment planning methods. He proposed using common indicators together with the new quality indicators, the so-called signal/noise - $S / N$ ratio which has a very significant role in the methodology [13].

Taguchi design is used to determine optimal parameter values and to determine the influence of independent variables on the studied process or product. Taguchi method uses a special design of orthogonal arrays to investigate the broad influence of parameters with a small number of experimental samples [14].

The goal of the quality improvement effort is to identify factors under control that are involved in the production process in order to maximize the $S / N$ ratio. Thus, the factors in the experiment are control factors.

Quality can be quantified (valued) in terms of the product response to the noise factors and the signal factors. The ideal product will only respond to the operator's signals and will be unaffected by random noise factors. Therefore, the goal of the quality improvement effort can be expressed as an attempt to maximize the $S / N$ ratio for the respective product.

The $S / N$ ratios proposed by Taguchi (1987) for different forms of loss functions $[15,16]$ have the following form:

- For $N$ type, the first form of Taguchi loss function, in cases when an average target response value is desired:

$$
S / N=10 \cdot \log \left(\frac{\bar{y}^{2}}{S^{2}}\right) .
$$

Where:

- the average value of the process response is:

$$
\bar{y}=\frac{1}{n} \sum_{i=1}^{n} y_{i},
$$

- the standard deviation is:

$$
S=\sqrt{\sum_{i=1}^{n} \frac{\left(y_{i}-\bar{y}\right)^{2}}{n-1}},
$$

where: $y_{i}-$ is the studied parameter, and $n-$ is the number of experiments.

- For type B, the second form of Taguchi loss function, in cases when a maximum target response value is desired:

$$
S / N=-10 \cdot \log \left(\frac{1}{n} \sum_{i=1}^{n} \frac{1}{y_{i}^{2}}\right) .
$$

- For type $S$, the third form of Taguchi function in cases when the target response value is about zero:

$$
S / N=-10 \cdot \log \left(\frac{1}{n} \sum_{i=1}^{n} y_{i}^{2}\right) .
$$

These $S / N$ indicators are derived from the quadratic loss function and are expressed in decibel scale $(\mathrm{dB})$.

When all the $S / N$ indicators are calculated for each experimental stage, Taguchi proposes a graphical approach for data analysis.

\section{Experimental part}

In this paper, we have tried to establish the values of the influential parameters that yield the highest values of the flow rate and the volumetric efficiency. The considered factors are the coefficient of the trochoid radius, the number of revolutions and the working pressure of the gerotor pump. In order to perform the

\begin{tabular}{|c|c|c|c|c|}
\hline \multirow{2}{*}{ Symbol } & \multirow{2}{*}{ Factor } & \multicolumn{3}{|c|}{ Level } \\
\hline & & 1 & 2 & 3 \\
\hline A & $\begin{array}{l}\text { Coefficient of the trochoid } \\
\text { radius }\end{array}$ & 1.375 & 1.575 & 1.675 \\
\hline $\mathrm{B}$ & Number of revolutions $\left(\mathrm{min}^{-1}\right)$ & 500 & 1000 & 2000 \\
\hline $\mathrm{C}$ & Pressure (bar) & 1 & 5 & 10 \\
\hline
\end{tabular}
analysis using Taguchi method, three levels have been chosen for each factor. Values of influential factors for all the levels are given in Tab. 1 .

Table 1 Levels of basic factors

Our study involved testing of the pump with different gear pairs built in (Fig. 1). Measurements were performed for three models of gear pairs, in the laboratory of the company PPT Hidraulika, by simulating actual operating conditions of the pump.

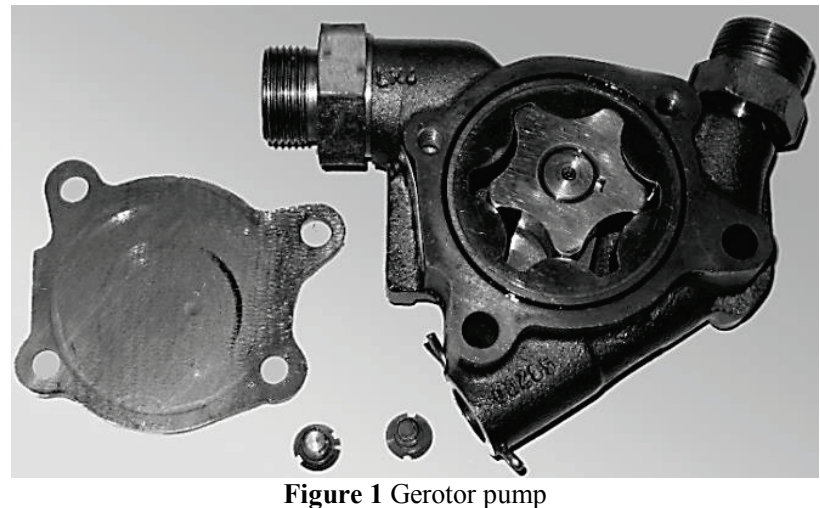

The testing plan was made in accordance with the internal standards of the company. In order to minimize the influence of the housing geometry, all the models of the pump gear pairs were tested in the same housing. Prior to testing, the stability of the working parameters (the pressure, the number of revolutions and the temperature) was checked. The stability of these 
parameters was also maintained during the measurements, which enabled all the models to be tested in approximately same conditions [17].

Based on the measured flow rate values for different models and different test parameters, values of the volumetric efficiency were determined [17]. The volumetric efficiency represents the ratio between the measured flow rate value at the working pressure and the measured flow rate value at the lowest pressure values at the pump outlet.

Table 2 Orthogonal matrix L9 with experimental results and calculated $S / N$ ratios

\begin{tabular}{|c|c|c|c|c|c|c|c|}
\hline Experiment & $\mathrm{A}$ & $\mathrm{B}$ & $\mathrm{C}$ & $\begin{array}{c}Q \\
1 / \mathrm{min}\end{array}$ & $\eta$ & $\begin{array}{c}S / N \text { for } Q \\
\mathrm{~dB}\end{array}$ & $\begin{array}{c}S / N \text { for } \eta \\
\mathrm{dB}\end{array}$ \\
\hline 1 & 1.375 & 500 & 1 & 6.90 & 0.9928 & 16.7770 & -0.06276 \\
\hline 2 & 1.375 & 1000 & 59 & 13.10 & 0.9704 & 22.3454 & -0.26098 \\
\hline 3 & 1.375 & 2000 & 10 & 25.70 & 0.9536 & 28.1987 & -0.41268 \\
\hline 4 & 1.575 & 500 & 59 & 6.30 & 0.9130 & 15.9868 & -0.79058 \\
\hline 5 & 1.575 & 1000 & 109 & 12.00 & 0.8791 & 21.5836 & -1.11923 \\
\hline 6 & 1.575 & 2000 & 19 & 27.10 & 1.0000 & 28.6594 & 0.00000 \\
\hline 7 & 1.675 & 500 & 10 & 5.55 & 0.7986 & 14.8859 & -1.95341 \\
\hline 8 & 1.675 & 1000 & 1 & 13.40 & 1.0000 & 22.5421 & 0.00000 \\
\hline 9 & 1.675 & 2000 & 59 & 26.20 & 0.9813 & 28.3660 & -0.16396 \\
\hline
\end{tabular}

Table 3 Results of the flow rate change analysis

\begin{tabular}{|c|c|c|c|c|c|c|c|}
\hline Source & $D F$ & Seq SS & Adj SS & Adj MS & $F$ & $P$ \\
\hline A & 2 & 0.051 & 0.051 & 0.025 & 0.72 & 0.583 \\
\hline B & 2 & 628.931 & 628.931 & 314.465 & 8913.98 & 0.000 \\
\hline C & 2 & 2.887 & 2.887 & 1.444 & 40.92 & 0.024 & 0.47 \\
\hline Residual Error & 2 & 0.071 & 0.071 & 0.035 & & \\
\hline Total & 8 & 631.939 & & & & \\
\hline
\end{tabular}

Table4 Results of the volumetric efficiency analysis

\begin{tabular}{|c|c|c|c|c|c|c|c|}
\hline Source & $D F$ & Seq SS & Adj SS & Adj MS & $F$ & $P$ \\
\hline A & 2 & 0.003827 & 0.003827 & 0.001913 & 2.05 & 0.328 & 10.30 \\
\hline B & 2 & 0.009053 & 0.009053 & 0.004527 & 4.85 & 0.171 & 24.37 \\
\hline C & 2 & 0.022396 & 0.022396 & 0.011198 & 12.00 & 0.077 & 60.30 \\
\hline Residual Error & 2 & 0.001866 & 0.001866 & 0.000933 & & \\
\hline Total & 8 & 0.037142 & & & \\
\hline
\end{tabular}

\subsection{Statistical analysis and discussion on the experimental results}

Experimental results for the flow rate and the volumetric efficiency for different factor levels are shown in Tab. 2. For the analysis of the obtained experimental results, the orthogonal matrix L9 was used. Q denotes the experimental flow rate results expressed in $1 / \mathrm{min}$, while $\eta$ denotes the volumetric efficiency results.

Tab. 2 also shows $S / N$ ratio results for the flow rate and the volumetric efficiency obtained using statistical software Minitab 16 [10].

The ANOVA results obtained for the flow rate are given in Tab. 3, while the volumetric efficiency results are given in Tab. 4 [18].

Based on the percentage share for $Q$ (Tab. 4) it can be concluded that the number of revolutions with $99.53 \%$ has the greatest influence, while the coefficient of the trochoid radius and errors has no significant influence (approximately zero). The pressure with $60.30 \%$ has the greatest influence on the volumetric efficiency (Tab. 4), while coefficient of the trochoid radius and the number of revolutions have significant influence with $10.30 \%$ and with $24.73 \%$, respectively.

Graphical representations of the influence of the analysed factors $\mathrm{A}, \mathrm{B}$ and $\mathrm{C}$ on the flow rate and the volumetric efficiency are given in Figs. 2, 3, 4 and 5.

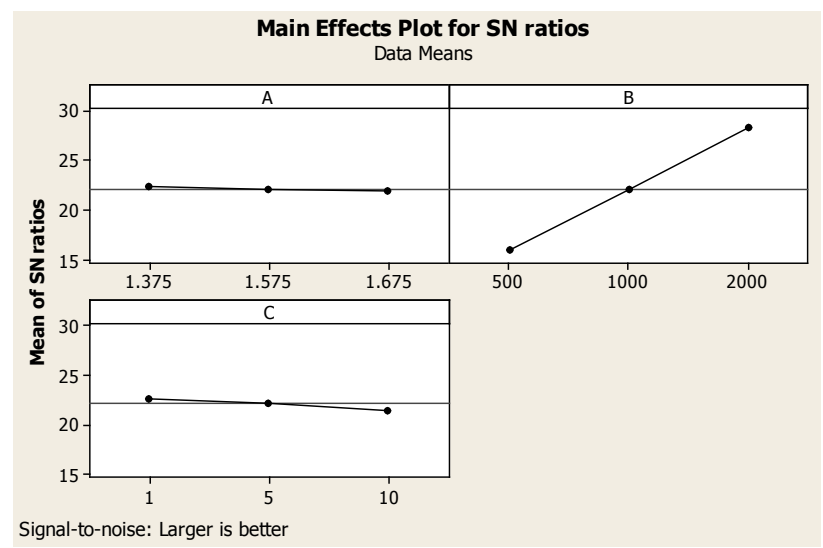

Figure 2 The effect of the factor based on the $\mathrm{S} / \mathrm{N}$ ratio for the flow

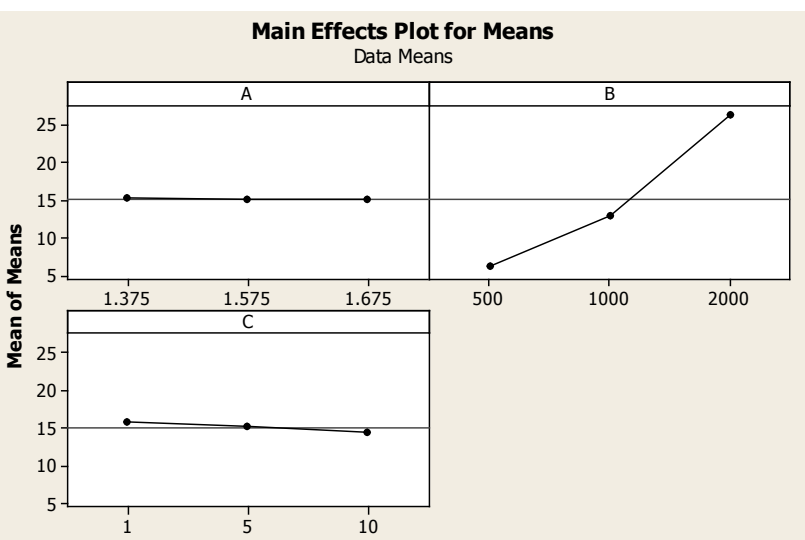

Figure 3 The effect of the factor based on the mean value for the flow 

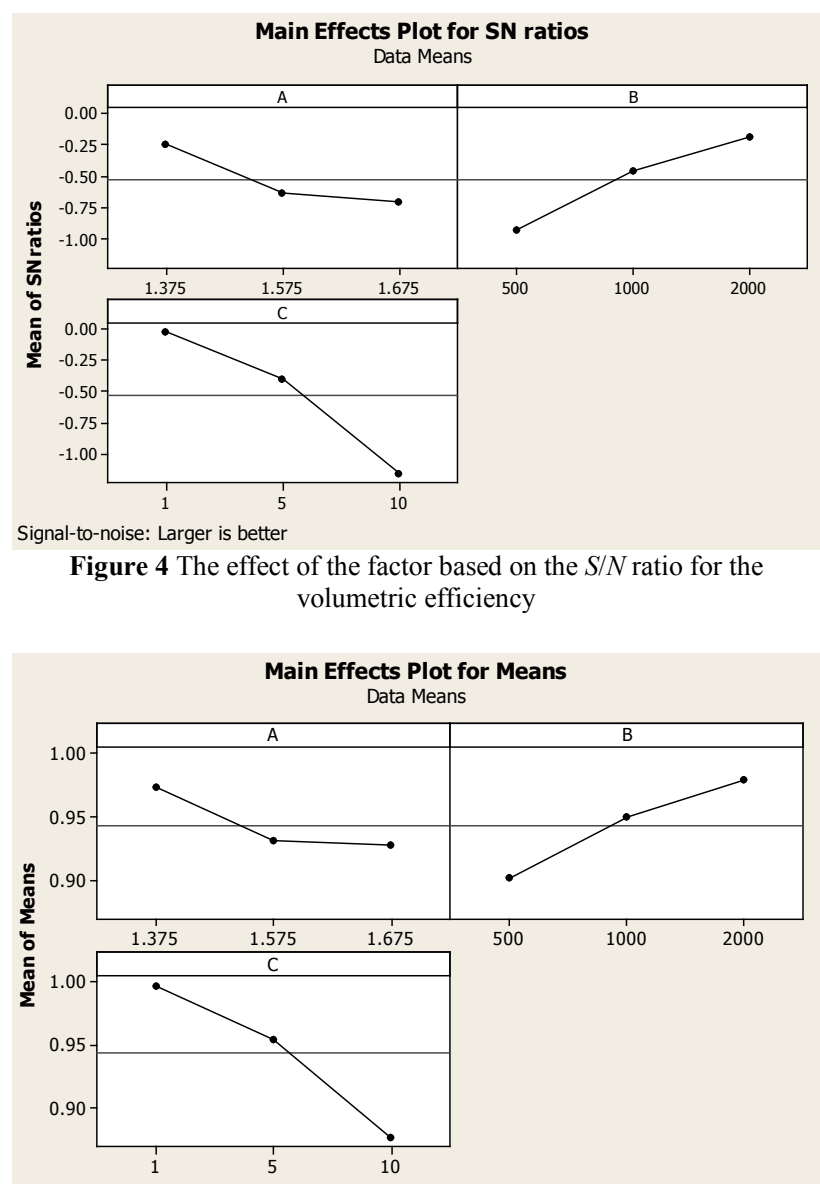

Figure 5 The effect of the factor based on the mean value of the volumetric efficiency

The range of the factors influence and factor ranking based on the $S / N$ ratio for the flow rate mean value when larger-is-better is shown in Tabs. 5 and 6 .

Table 5 The range of the factor influence and factor ranking based on

\begin{tabular}{|c|c|c|c|}
\multicolumn{5}{|c|}{ the $S / N$ ratio for the flow rate } \\
\hline Level & $\mathrm{A}$ & $\mathrm{B}$ & $\mathrm{C}$ \\
\hline 1 & 22.44 & 15.88 & 22.66 \\
\hline 2 & 22.08 & 22.16 & 22.23 \\
\hline 3 & 21.93 & 28.41 & 21.56 \\
\hline$\Delta$ & 0.51 & 12.52 & 1.10 \\
\hline Rank & 3 & 1 & 2 \\
\hline
\end{tabular}

Table 6 The range of the factor influence and factor ranking based on the mean value for the flow rate

\begin{tabular}{|c|c|c|c|}
\hline Level & $\mathrm{A}$ & $\mathrm{B}$ & $\mathrm{C}$ \\
\hline 1 & 15.233 & 6.250 & 15.800 \\
\hline 2 & 15.133 & 12.833 & 15.200 \\
\hline 3 & 15.050 & 26.333 & 14.417 \\
\hline$\Delta$ & 0.183 & 20.083 & 1.383 \\
\hline Rank & 3 & 1 & 2 \\
\hline
\end{tabular}

Table 7 The range of the factor influence and factor ranking based on the $S / N$ ratio for the volumetric efficiency

\begin{tabular}{|c|c|c|c|}
\hline Level & $\mathrm{A}$ & $\mathrm{B}$ & $\mathrm{C}$ \\
\hline 1 & -0.24547 & -0.935599 & -0.02092 \\
\hline 2 & -0.63661 & -0.460907 & -0.40518 \\
\hline 3 & -0.70579 & -0.199221 & -1.16177 \\
\hline$\Delta$ & 0.46032 & 0.749337 & 1.14085 \\
\hline Rank & 3 & 92 & 1 \\
\hline
\end{tabular}

The factor B, i.e. the number of revolutions, has the greatest effect on the increase of the flow rate, which is compliant with the above stated.

The range of the factor influence and factor ranking based on the $S / N$ ration for the volumetric efficiency for the case when larger is better is given in Tabs. 7 and 8 .

Table 8 The range of the factor influence and factor ranking based on the mean value for the volumetric efficiency

\begin{tabular}{|c|c|c|c|}
\hline Level & $\mathrm{A}$ & $\mathrm{B}$ & $\mathrm{C}$ \\
\hline 1 & 0.9723 & 0.9015 & 0.9976 \\
\hline 2 & 0.9307 & 0.9498 & 0.9549 \\
\hline 3 & 0.9266 & 0.9783 & 0.8771 \\
\hline$\Delta$ & 0.0456 & 0.0768 & 0.1205 \\
\hline Rank & 3 & 2 & 1 \\
\hline
\end{tabular}

The factor $\mathrm{C}$, the pressure, has the greatest influence on the increase of the volumetric efficiency.

The optimal variant for the flow and the volumetric efficiency is A1B3C1 (A1 $=1.375, \mathrm{~B} 3=2000 \mathrm{~min}^{-1}, \mathrm{C} 1$ $=1 \mathrm{bar}$ ) based on the shown diagrams and the factor influence range when larger-is-better.

\subsection{Experiment confirmation}

The equation used for confirmation of the experiment $[14,19]$ is:

$C I=\sqrt{F_{\alpha: 1, V_{2}} \cdot V_{\mathrm{e}} \cdot\left(\frac{1}{n_{\mathrm{eff}}}+\frac{1}{r}\right)}$

where: $F_{\alpha: 1, V_{2}}$ is 18.5128 for $\alpha=0.05$ or for the probability of $95 \%$ by Fisher and for 2 degrees of freedom for error; $V_{\mathrm{e}}$ represents the Adj $M S$ error and it is 0.035 for the flow change and 0.000933 for the volumetric efficiency;

$n_{\text {eff }}=\frac{\text { total experimental trials }}{1+\left(\begin{array}{l}\text { total degree of freedom of } \\ \text { factors for prediction }\end{array}\right)}$.

In that case $n_{\text {eff }}=1,2857 ; r$ - the number of repeats is 1 in this case.

The confidence interval for confirmation of the experiment [19] is given by the equations (11) and (12).

The solutions of the Eq. (6) for the flow change and the volumetric efficiency are given with the expressions (7) and (8).

$$
\begin{aligned}
& C I(Q)=1.073 \\
& C I(\eta)=0.175
\end{aligned}
$$

In order to obtain the solution interval for the confirmation of the experiment, the Eqs. (9) and (10) are used for the flow and the volumetric efficiency, respectively:

$$
\begin{aligned}
& Q_{p}=T_{Q}+\left(\mathrm{A} 1-T_{Q}\right)+\left(\mathrm{B} 3-T_{Q}\right)+\left(\mathrm{C} 1-T_{Q}\right), \\
& \eta_{p}=T_{\eta}+\left(\mathrm{A} 1-T_{\eta}\right)+\left(\mathrm{B} 3-T_{\eta}\right)+\left(\mathrm{C} 1-T_{\eta}\right) .
\end{aligned}
$$


The symbols A1, B3 and Clin the equations (9) and (10) represent the optimal variant. Their values for the flow $\mathrm{A} 1=15.233, \mathrm{~B} 3=26.333, \mathrm{C} 1=15.800$ are the highest mean values in Tab. 6, while the values for the volumetric efficiency $\mathrm{A} 1=0.9723, \mathrm{~B} 3=0.9783$ and $\mathrm{C} 1=$ 0.9976 are the highest mean values in Tab. 8 .

The parameter $T$ in the Eqs. (9) and (10) is defined by the expression:

$$
T=\frac{\text { sum of recalls }}{\text { total number of experiments }} \text {. }
$$

The value of this parameter is $T_{Q}=15.1389$ for the flow rate, and $T_{\eta}=0.9432$ for the volumetric efficiency.

The solution of the Eq. (9) is $Q_{p}=27.0882$, while the solution of the Eq. (10) is $\eta_{p}=1.0618$.

The solution interval for the flow change is given by the Eq. (11), and it is

$Q_{p}-C I \leq Q_{p} \leq Q_{p}+C I$

$26.0152 \leq Q_{p} \leq 28.1612$,

while the Eq. (12) gives the solution interval for the volumetric efficiency

$$
\begin{aligned}
& \eta_{p}-C I \leq \eta_{p} \leq \eta_{p}+C I \\
& 0.8868 \leq \eta_{p} \leq 1.2368 .
\end{aligned}
$$

Since the volumetric efficiency is never 1 or higher than 1 , the relation $0.8868 \leq \eta_{p}<1$ applies for the optimal variant.

\section{Conclusion}

It has been shown that applying Taguchi method and statistical analysis of experimental data, a small number of experimental results can be used to identify the most influential factors and determine their optimal combination.

It has been noticed that the number of revolutions has the greatest influence on the flow rate change of the gerotor pump, while the pressure has the greatest influence on its volumetric efficiency.

The greatest flow rate and volumetric efficiency values were obtained for the optimal variant of the gerotor pump with the coefficient of the trochoid radius of 1.375 , the number of revolutions of $2000 \mathrm{~min}^{-1}$ and the working pressure of 1 bar.

The confirmation of the experiment for the optimal factor values has shown that the flow change will vary in the range from $26 \mathrm{l} / \mathrm{min}$ to $28 \mathrm{l} / \mathrm{min}$, and that the least value of the volumetric efficiency is 0.8868 .

\section{Acknowledgements}

This paper presents the research results obtained within the framework of the projects TR-35021 and TR35033 financially supported by the Ministry of Education, Science and Technological Development of the Republic of Serbia.

\section{References}

[1] Ivanović, L.; Blagojević; M.; Deverdžić, G.; Assoul, Y. Analitycal and Numerical Analysis of Load Gerotor Pumps. // Scientific Technical Review, 60, 1(2010), pp. 30-38.

[2] Prakash, H. R.; Manjula, S. Design and Analysis of Gerotors of Main Gear Box Lubricating Oil Pump. // International Journal of Engineering and Technical Research, 2, 5(2014), pp. 79-81.

[3] Ivanović, L.; Josifović, D.; Ilić, A.; Stojanović, B. Analytical model of the pressure variation in the gerotor pump chambers. // Technics Technologies Education Management, 8, (2013), pp. 323-331.

[4] Miković, J. Investigation of the mechanical properties of plastic masses by application of Taguchi method (In Serbian). MSc Thesis, Faculty of Engineering in Kragujevac, Kragujevac, 2013.

[5] Kim, M. S.; Chung, W. J.; Jung, C. D.; Park, S. S.; Ahn H. C.; Kim, H. C. On New Methodology of AMESim\& CATIA V5 - based Cavitation Simulation for Flow Rate Control of Trochoid Hydraulic Pump, International Conference on Mechatronics and Automation, Beijing, China, 2011, pp. 7-10.

[6] Hwang, Y.; Hsieh, C. Determination of surface singularities of a cycloidal gear drive with inner meshing, Mathematical and Computer Modelling, 45, 3-4(2007), pp. 340-354.

[7] Hwang, Y.; Hsieh, C. Geometric Design Using Hypotrochoid and Nonundercutting Conditions for an Internal Cycloidal Gear, Journal of Mechanical Design, 129, 4(2007), pp. 413-420.

[8] Reza, M. Elliptical lobe shape gerotor pump design to minimize wear, Education Press and Springer-VerlagBernin Heidelberg, 2011.

[9] Sung-Yuen, J.; Moon-Saeng, K.; Chul, K. Development of a New Gerotor for Oil Pumps with Multiple Profiles (Ellipse1, Involute and Ellipse2), Journal of the Korean Society of Precision Engineering, Korean Society of Precision Engineering, 28, 5(2011), pp. 614-622.

[10] Meet Minitab 16, Minitab Inc., 2010.

[11] Roy, R. K. Design of Experiments Using the Taguchi Approach: 16 Steps to Product and Process Improvement. Wiley-Interscience, NewYork, 2001.

[12] Ivić, K.; Marinković, R.; Jurković, Z. Management of changes by application of Taguchi method. // Ekonomski Vjesnik, Osijek, 1(2011), pp. 211-217. (in Croatian)

[13] Spasojević, K. Presentation of Taguchi method with practical examples. // Diploma paper, Faculty of Mechanical Engineering, Kragujevac, 1996. (in Serbian)

[14] Puh, F.; Šegota, T.; Jurković, Z. Optimization of hard turning process parameters with PCBN tool based on the Taguchi method. // Tehnicki vjesnik-Technical Gazette, 19, 2(2012), pp. 415-419.

[15] Ukrainczyk, M. Design of Experiments in Industry. // Croatian journal of food technology, biotechnology and nutrition, 5, 3-4(2010), pp. 96-105.

[16] Miković, J.; Veličković, S.; Aleksandrović, S.; Adamović, D.; Ćatić, D. Application of Taguchi methods in testing tensile strength of Polyethylene. $/ / 8^{\text {th }}$ International Quality Conference, Centre for Quality, Faculty of Engineering, University of Kragujevac, 2014.

[17] Ivanović, L. Identification of the Optimal Shape of Trochoid Gear Profile of Rotational Pump Elements. // PhD thesis, The Faculty of Mechanical Engineering in Kragujevac, Kragujevac, 2007.

[18] Hricova, J.; Kovac, M.; Sugar, P. Experimental Investigation of High Speed Milling Of Aluminium Alloy. // Tehnicki vjesnik-Technical Gazette, 21, 4(2014), pp. 773777.

[19] Krishnaiah, K.; Shalabudeen, P. Applied design of Experiments and Taguchi methods, New Delhi, 2012. 


\section{Authors' addresses}

Lozica Ivanović, PhD, associate professor

Faculty of Engineering, University of Kragujevac

Sestre Janjić 6, 34000 Kragujevac, Serbia

E-mail: lozica@kg.ac.rs

Blaža Stojanović, PhD, assistant professor

Faculty of Engineering, University of Kragujevac

Sestre Janjić 6, 34000 Kragujevac, Serbia

E-mail: blaza@kg.ac.rs

\section{Jasmina Blagojević, PhD student}

Faculty of Engineering, University of Kragujevac

Sestre Janjić 6, 34000 Kragujevac, Serbia

E-mail: jacab@kg.ac.rs

Gordana Bogdanović, PhD, assistant professor

Faculty of Engineering, University of Kragujevac

Sestre Janjić 6, 34000 Kragujevac, Serbia

E-mail: gocab@kg.ac.rs

Aleksandar Marinković, PhD, associate professor

Faculty of Mechanical Engineering, University of Belgrade

Kraljice Marije 16, 11000 Belgrade, Serbia

E-mail: amarinkovic@mas.bg.ac.rs 